\title{
PELATIHAN PEMBUATAN MIE DARI BAHAN DASAR TEPUNG MODIFIED CASAVA FLOUR (Mocaf) SEBAGAI UPAYA PENINGKATAN WAWASAN PENGETAHUAN DAN PELUANG USAHA BAGI IBU-IBU PKK DI DESA JAYA SAKTI MUARAGEMBONG KABUPATEN BEKASI
}

I. Gusti Ayu Ngurah S

Jurusan Ilmu Kesejahteraan Keluarga, Fakultas Teknik Universitas Negeri Jakarta

\begin{abstract}
ABSTRAK
Pengabdian ini mempunyai tujuan untuk memberikan pengetahuan dan pengajaran mengenai pembuatan tepung mocaf dan penggunaannya sebagai bahan dasar pengganti tepung terigu dalam pembuatan mie sehingga dapat membantu ibu-ibu di Desa Jaya Sakti dalam memenuhi kebutuhan mereka membuat mie dari tepung mocaf dengan harapan hasil produk dapat dijual sehingga dapat menambah income bagi keluarga mereka.

Khalayak sasaran adalah Ibu-ibu PKK dan warga sekitar Desa Jaya Sakti. Pelatihan ini di laksanakan dalam satu kali pertemuan, Pertemuan dilakukan di rumah Kepala Desa Jaya Sakti Muaragembong Bekasi

Pertemuan diawali dengan pembukaan kemudian memberikan materi dan praktek pembuatan tepung mocaf, dan pembuatan mie dari tepung mocaf. Untuk bahan dasar mie tepung mocaf digunakan yang telah siap pakai.

Tepung Mocaf (Modified Cassava Flour), adalah produk tepung dari ubi kayu/singkong yang diperoses menggunakan prinsip memodifikasi sel ubi kayu dengan cara fermentasi. Mikroba yang tumbuh menyebabkan perubahan karakteristik pada tepung yang dihasilkan, yaitu naiknya viskositas, kemampuan gelasi, daya rehidrasi, dan kemudahan melarutkan. Mikroba juga menghasilkan asam-asam organic, terutama asam laktat yang akan terimbibisi dalam tepung, dan ketika tepung itu diolah akan menghasilkan aroma dan citra rasa khas, yang dapat menutupi aroma dan citra rasa ubi kayu yang cenderung tidak menyenangkan konsumen. Tekstur dan warna tepung mocaf ini lebih halus dan lebih putih dari tepung terigu.

Untuk pengembangan lebih lanjut, maka tepung mocaf diaplikasikan untuk membuat mie, selain nilai jualnya lebih baik lagi karena menghasilkan produk yang lain dan langsung bisa di konsumsi.

Dari hasil kegiatan pengabdian ini terlihat antusias dari para peserta, karena mereka senang mendapatkan pengetahuan baru yang dapat mereka praktekkan di rumah masingmasing.
\end{abstract}

Kata Kunci : tepung mocaf, mie 


\section{PENDAHULUAN}

Tepung Mocaf adalah tepung yang dihasilkan dari singkong atau ketela pohon, rekayasa modifikasi tepung cassava (singkong) dengan teknik fermentasi bertujuan menghasilkan tepung yang dapat meminimalkan sifat kurang suka.

Umbi singkong merupakan sumber energi yang kaya karbohidrat namun sangat rendah protein. Sumber protein yang bagus justru terdapat pada daun singkong karena mengandung asam amino metionin. Selain umbi akar singkong banyak mengandung glukosa dan dapat dimakan mentah. Rasanya sedikit manis, ada pula yang pahit tergantung pada kandungan racun glukosida yang dapat membentuk asam sianida.Umumnya daging umbi singkong berwarna putih atau kekuning kuningan, untuk rasanya manis menghasilkan paling sedikit $20 \mathrm{mg}$ HCN per kilogram umbi akar yang masih segar dan 50 kali lebih banyak pada umbi yang rasanya pahit. Pada jenis singkong yang pahit, proses pemasakan sangat diperlukan untuk menurunkan kadar racunnya.

Tanaman singkong memiliki akar serabut dan pada akarnya ini biasanya terdapat bagian yang mengalami pembesaran bagian inilah yang merupakan tempat menyimpan cadangan makanan. Cadangan makanan yang disimpan sebagian besar berupa zat tepung oleh karena itu akar atau umbi singkong banyak di konsumsi bahkan di beberapa daerah dijadikan makanan pokok pengganti nasi.

Singkong banyak digunakan pada berbagai macam penganan, mulai dari kripik, kudapan, sayuran hingga tape. Bahkan bisa juga dibuat tepung singkong yaitu tepung tapioka yang dapat digunakan untuk mengganti tepung gandum, tepung ini baik untuk pengidap alergi.
Usaha penganekaragaman pangan sangat penting artinya sebagai usaha untuk mengatasi masalah ketergantungan pada satu bahan pangan pokok saja. Misalnya dengan mengolah serealia dan umbi-umbian menjadi berbagai bentuk awetan yang mempunyai rasa khas dan tahan lama disimpan. Bentuk olahan tersebut berupa tepung, gaplek, tapai, keripik dan lainya. Hal ini sesuai dengan program pemerintah khususnya dalam mengatasi masalah kebutuhan bahan pangan, terutama non-beras. Ubi kayu atau singkong merupakan salah satu bahan makanan sumber karbohidrat (sumber energi).

\begin{tabular}{|c|c|}
\hline \multicolumn{2}{|c|}{$\begin{array}{l}\text { Tabel 1. Komposisi Ubi Kayu (per } 100 \text { gra } \\
\text { bahan) }\end{array}$} \\
\hline KOMPONEN & KADAR \\
\hline Kalori & $146,00 \mathrm{kal}$ \\
\hline Air & 62,50 gram \\
\hline Phosphor & $40,00 \mathrm{mg}$ \\
\hline Karbohidrat & 34,00 gram \\
\hline Kalsium & $33,00 \mathrm{mg}$ \\
\hline Vitamin C & $30,00 \mathrm{mg}$ \\
\hline Protein & 1,20 gram \\
\hline Besi & $0,70 \mathrm{mg}$ \\
\hline Lemak & 0,30 gram \\
\hline Vitamin B1 & $0,06 \mathrm{mg}$ \\
\hline Berat dapat dimakan & 75,00 \\
\hline
\end{tabular}

\section{BAHAN DAN METODE}

\section{A. Kerangka Pemecahan Masalah}

Mie sudah menjadi makanan yang popular di Indonesia. Pembuatan mie juga tidak terlalu sukar bisa dilakukan sendiri di rumahrumah. Mie yang dibuat dapat digunakan untuk resep bakso dan mie ayam, yang merupakan masakan amat popular di Indonesia

Melalui kegiatan pengabdian masyarakat ini, peserta akan dipandu bagaimana cara membuat tepung mocaf dan 
bahan, alat dan cara membuatnya, perkenalan ini bertujuan agar ibu PKK yang masih pemula, karena disusun dengan langkah yang mudah dipahami. Serta dipilih jenis pembuatan mie yang sederhana dengan bahan tepung mocaf yang sudah siap pakai.

Kebanyakan ibu-ibu di desa Jaya Sakti membuka warung kecil untuk tambahan pemasukan keluarga. Sehingga pengetahuan pembuatan mie dari tepug mocaf dapat membantu ibu-ibu memproduksi mie sendiri di rumah dan dapat menjualnya sebagai kuliner mie bakso dan mie ayam.

Memberikan pelatihan bagi ibu-ibu PKK di Desa Jaya Sakti dengan cara pendekatan secara internal dan external . Secara internal adalah rangsangan yang datang dari dalam diri seorang seperti keinginan hasrat dan motivasi untuk maju. Sedangkan eksternal adalah rangsangan yang datangnya dari luar diri seseorang seperti ajakan untuk kegiatan pembuatan mie dari tepung mocaf.

\section{B. Reliasasi Pemecahan Masalah}

Reliasasi pemecahan masalah ini dilakukan dengan mengadakan pelatihan sehingga peserta dapat membuat mie dari mocaf sekaligus mampu membuat tepung mocaf untuk dijadikan bahan baku dalam pembuatan mie dan merancang harga jual dari produk yang dihasilkan.

\section{Khalayak Sasaran}

Khalayak sasaran dalam pelatihan ini adalah sebanyak 20 orang dari sosial ekonomi rendah dan kader PKK Desa Jaya Sakti

\section{Metode yang Digunakan}

Mengingat jenis kegiatan ini adalah praktek dan eksperimen maka metode yang digunakan adalah :

- $30 \%$ teori berupa ceramah

- 70 \% berupa demo dan praktek langsung tentang pembuatan tepung mocaf dan mie dari tepung mocaf dengan pengawasan dan penjelasan langsung dari Tim Pelaksana Pelatihan.

\section{HASIL DAN PEMBAHASAN}

A. Pembuatan Tepung Mocaf fermentasi yang menyebabkan tepung mocaf memiliki tekstur yang berbeda dengan tepung singkong biasa. Perbedaan tepung mocaf dengan tepung singkong dan tepung gaplek terletak pada proses pengolahannya. Tepung singkong atau tepung cassava dibuat dari singkong yang dikupas, dipotong-potong menjadi chips, dikeringkan, kemudian ditepungkan. Tepung gaplek dibuat dari singkong yang dibuat gaplek terlebih dahulu, kemudian ditepungkan. Sementara itu, tepung mocaf dibuat dibuat dengan cara singkong dipotong-potong menjadi chips, kemudian difermentasikan dahulu, dikeringkan, kemudian digiling.

Karakteristik tepung singkong dan tepung gaplek hampir sama. Kedua tepung itu memiliki aroma khas singkong yaitu agak apek. Warna tepung singkong lebih putih dibandingkan tepung gaplek, tetapi tepung singkong memiliki aroma khas singkong lebih kuat. Tepung singkong dan tepung gaplek kurang disukai oleh masyarakat karena warnanya yang kurang putih dan aroma singkongnya yang begitu kuat. Sementara itu, tepung mocaf berwarna lebih putih, dan aroma khas singkong lebih sedikit.

Tepung mocaf memiliki kandungan nutrisi yang berbeda dari tepung terigu. Perbedaan kandungan nutrisi yang mendasar adalah tepung mocaf tidak mengandung zat guleten-zat yang hanya ada pada terigu, yang menetukan kekenyalan makanan. Tepung mocaf berbahan baku singkong memiliki sedikit protein, tepung mocaf lebih kaya karbohidrat dan memiliki glasi yang lebih rendah dibandingkan tepung terigu. Dibandingkan dengan tepung singkong biasa tepung mocaf memiliki karakter derajat viskositas (daya rekat), kemampuan gelasi daya rehidrasi, dan kemudian melarut yang lebih baik.

Perbandingan komposisi kimiawi tepung terigu versus tepung mocaf

\begin{tabular}{|l|l|l|l|}
\hline NO & Komponen & Mocaf & Terigu \\
\hline 1 & Kadar air & $6,9 \%$ & $12 \%$ \\
\hline 2 & Kadar protein & $1,2 \%$ & $8-13 \%$ \\
\hline 3 & Kadar abu & $0,4 \%$ & $1,3 \%$ \\
\hline 4 & Kadar pati & $87,3 \%$ & $60-68 \%$ \\
\hline 5 & Kadar serat & $3,4 \%$ & $2-2,5 \%$ \\
\hline 6 & Kadar lemak & $0,4 \%$ & $1,5-2 \%$ \\
\hline
\end{tabular}

Pada tepung mocaf dengan pengeringan yang optima, kadar air mencapai 6,9\%, sedangkan pada tepung terigu mencapai $12 \%$. Kadar air yang lebih rendah menyebakan tepung ini lebih tahan terhadap pertumbuhan jamur yang dapat menyebakan kerusakan 


\section{P-ISSN : 0216-7484 \\ DOI : doi.org/10.21009/sarwahita.121.09}

priedudariTeppung moceaff,memlbikidaumumenigqued yang lebih lama dibandingkan terigu.

Saat ini teknik fermentasi yang digunakan untuk menghasilkan tepung mocaf umumnya menggunakan bakteri asam laktat dan enzimatis. Berbagai bakteri asam laktat telah diuji coba dan digunakan untuk memproduksi tepung mocaf. Bakteri ini aman untuk proses pengolahan pangan dan mampu menghasilkan produk tepung mocaf dengan kualitas yang cukup baik. Bakteri asam laktat memiliki kemampuan mengubah berbagai senyawa yang terdapat pada media menjadi senyawa yang lebih sederhana sehingga memberi flavor dan aroma yang lebih baik pada makanan (Marrug,1991). Bakteri ini memiliki pertumbuhan optimal pada suhu $30-37^{0}$.

Berikut ini cara pembuatan tepung mocaf : Persiapan Alat :

1. Timbangan Kap. 1000gr untuk menimbang bahan di bawah 1000 gr

2. Kompor gas/minyak tanah

3. Corong plastik untuk memasukkan air kelapa

4. Saringan

5. Panci stainless kap. 30 liter untuk mendidihkan/ merebus bahan.

6. Kertas Koran ukuran $7 \times 7 \mathrm{~cm}$, diginakan untuk menutup bola pada saat inkubasi

7. Botol untuk media padam saat inkubasi

8. Gelas ukur plastic kapasitas 1 liter, alat ukur volume

9. Sikat botol plastic untuk membersihkan botol

10. Karet gelang untuk mengikat Koran penutup botol

11. Pengaduk kayu untuk mengaduk air kelapa

\section{B. Prosedur Kerja Pengembangbiakan Bibit Acetobacter xylinum}

1. Saring terlebih dahulu air kelapa, masukkan ke dalam panci ukuran 20 ltr.

2. Rebus sampai mendidih dengan menggunakan kompor atau tungku. Buang busa pada permukaan air kelapa selama proses perebusan.

3. Masukkan gula 200gr, ZA 60 gr,Cuka 90 $\mathrm{ml}$.

4. Seterilkan corong dan gelas takar yang akan digunaka untuk menuangkan ke

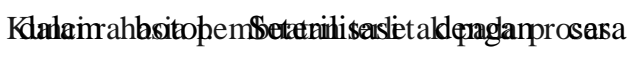
merebus dalam air mendidih kurang lebih 10 menit.

5. Siapkan botol, Koran penutup botol, karet gelang yang sudah dijemur terlebih dahulu.

6. Tuangkan media air kelapa tersebut ke dalam botol dengan menggunakan gelas takar hingga kurang lebih $520 \mathrm{ml}$.

7. Kemudian, segera tutup botol tersebut dengan menggunakan Koran. Untuk mengencanngkannya gunakan karet gelang. Usahakan menutup botol denngan Koran jangan ada yang renggang atau tidak tertutup rapt karena jika mulut botol basah akan terkontaminasi.

8. Setelah dingin kira-kira 7 jam, tambahkan cairan bibit dan kultur murni kurang lebih $100 \mathrm{ml}$ ke media dalam botol. Bibit Acetobacter yang digunakan adalah bibit yang berkualitas, umur tidak lebih dari 10 hari dan tidak terkontaminasi bakteri atau jamur lain.

9. Tutup kembali dengan Koran dan ikat dengan karet gelang. Selanjutnya simpanndalam ruangan yang tidak terkena matahari langsung tidak terkena goncangan, dan suhu ruang $28-32^{0} \mathrm{C}$.

Setelah diinkubasi selama 6 hari, bibit tersebut dapat digunakan untuk fermentasi bahan baku singkong yang telah dipotongpotong menjadi chips. Bibit yang akan digunakan disortasi terlebih dahulu. Gunakan bibit yang baik, tidak terkontaminasi. Kriteria bibit yang baik adalah terbentuknya lapisan tipis nata pada permukaan cairan, tidak terdapat jamur, umurnya tidak lebih dari 10 hari.

\section{Langkah Kerja Pembuatan Tepung Mocaf}

Setelah menyiapkan bibit Acetobacter xylinum sesuai dengan kebutuhan tingkat produksi yang direncanakan, langkah selanjutnya adalah menyiapkan alat dan bahan baku singkong.

TM Alat dan Bahan

Alat yang dibutuhkan antara lain:

1. Pisau untuk mengupas kulit singkong dan memotong singkong menjadi slice

2. Drum plastic $120 \mathrm{lt}$ 
chips singkong atau menampung tepung

4. Gayung

5. Tampah/terpal untuk penjemuran

6. Mesin penepung untuk menggiling chips singkong yang telah kering

7. Timbangan

8. Mesin slicing/pemotong

TM Bahan yang dibutuhkan adalah :

1. Singkong

2. Bibit Acetobacter xylinum

3. Air

\section{Proses Produksi}

Setelah alat dan bahan disiapkan, proses produksi tepung mocaf dapat dimulai, Alur pembuatan tepung mocaf adalah sebagai berikut:

1. Sortasi dan penimbangan

Sebelum singkong diproses, sortasi terlebih dahulu dilakikan pemisahan singkong yang rusak dan tidak memenuhi setandar mutu, kemudian dilakukan penimbangan agar dapat diketahui berat kotor dan berat bersih sehingga total produk jadi dapat dianalisis dan dapat dihitung tingkat kegagalannya.

2. Pengupasan

Pengupasan kulit singkong dapat dilakukan dengan menggunakan pisau. Singkong yang telah dikupas sebaiknya ditampung di dalam bak atau ember yang berisi air sehingga tidak menimbulkan warna kecokelatan sekaligus menghilangkan asan sianida (HCN).

3. Pencucian

Setelah di kupas singkong di cuci dengan air bersih, Hindari penggunaan air yang mengandung kaporit atau terkontaminasi bahan kimia. Penggunaan air yang mengandung kaporit menyebabkan pertumbuhan bakteri fermentasi terhambat.

4. Slicing/chiping (pemotongan)

Singkong yang telah dicuci bersih kemudian dipotong tipis-tipis berbentuk chips berukuran kurang lebih 0.2-0.3 cm. Pemotongan bisa dilakukan secara dengan menggunkan mesin slicing.

5. Fermentasi/Perendaman

Proses fementasi chips singkong dilakukan dengan menggunaka drum plastic yang diisi air, kemudian dilarutkan bakteri Acetobacter cylinum 10-20 \% dari volume chips dan air. Perendaman dilakukan sehingga seluruh chips tertutup air. Fermentasi dilakukan selama kurang lebih 2-3 hari (minimum 30 jam).

6. Pencucian

Setelah proses fermentasi selesai dilakukan pencucian kembali untuk menghilangkan sifat asam pada chips singkong hingga tidak berasa dan tidak berbau. Kemudian chips ditiriskan dengan menggunakan penjemur yang terbuat dari anyaman bamboo/tampah, dengan plat seng dengan ukuran $120 \mathrm{~cm}$ x $60 \mathrm{~cm}$, atau dapat menggunakan terpal. Penjemuran dengan menggunkan terpal lebih praktis, terutama jika hujan, sedangkan penjemuran dengan menggunakan nampan dan plat lebih cepat kering.

7. Pengeringan/Penjemuran

Pengeringan bisa dilakukan dengan menggunakan energy matahari. Jika Panas matahari normal maka penjemuran dapat dilakukan minimal 3 hari. Penjemuran dengan menggunakan energy matahari ini diperlukan lahan yang datar, luas, lapang dan tidak terhalang oleh pepohonan. Jika kita menginginkan kapasitas produksi besar tetapi tidak bergantung pada pengeringan energy matahari, maka pengeringan bisa dilakukan dengan mesin pengering yang lebih cepat dan besar.

8. Penepungan

Setelah chips benar-benar kering hingga mencapai kadar air maksimal 13\%, selanjutnya dilakukan proses penggilingan dengan menggunakan mesin penepung.

9. Pengayakan

Pengayakan dilakukan untuk menghasilkan tepung mocaf yang lembut. Pengayakan dapat dilakukan secara manual menggunakan saringan atau dengan menggunakan mesin sehingga 


\section{P-ISSN : 0216-7484 \\ DOI : doi.org/10.21009/sarwahita.121.09}

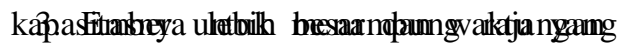
digunkan lebih singkat dengan mesh 60100. Untuk mendapatkan tepung mocaf yang harus gunakan saringan/ayakan dengan kerapatan yang tinggi. Tepung yang halus menentukan mutu produk.

10. Pengemasan

Seteleh singkong menjadi produk tepung, langkah selanjutnya adalah dikemas sesuai ukuran yang kita kehendaki. Jenis kemasan disesuaikan dengan pasar tujuan. Kemasan plastic umumnya digunakan untuk prooduk eceran, kemasan karung umunya ditujukan ke industry atau pedagang besar.

Untuk menghasilkan produk tepung mocaf sesuai standar mutu yang diinginkan dan aman untuk dikonsumsi, proses produksi harus dikerjakan sesuai standar operasional yang tepat. Ketidak disiplinan dalam melaksanakan standar operasional yang ditetapkan dapat mengakibat-kan risiko penurunan kwalitas, biaya produksi yang meningkat, produk cacat atau bahaya keamanan pangan. Setiap elemen yang terlibat dlam proses produksi khususnya harus melaksanakan sesuai standar operasi yang ditetapkan.

Mutu produk mocaf yang ingin dicapai adalah produk dengan karakteristik aroma tidak berbau singkong; warna putih; tidak terdapat kontaminasi berupa material fisik, bahan kimia; kadar air tidak melebihi standar, yaitu maksimal 13\%; tidak berasa asam; tekstur lembut. Tidak tercapainya standar mutu yang ditetapkan mengakibatkan penurunan harga jual yang pada akhirnya menyebabkan penurunan laba atau bahkan kerugian.

Sebagai contoh pengeringan yang tidak sempurna sehingga kadar air masih tinggi memiliki resiko terkontaminasi jamur.

\section{Pengertian Mie}

Mie adalah jenis makanan yang paling popular di negeri ini, dari anak-anak sampai orang dewasa sangat menyukainya. Mie juga salah satu jenis makanan yang popular di daratan Asia khususnya di Asia Timur dan Asia Tenggara. Menurut catatan tua yang merekam bahwa mie pertama kali dibuat saat jaman Dinasti Han di China sekitar 4000 tahun yang lalu dengan adanya penemuan mie tertua yang berumur 4000 tahun di daratan China pada tahun 2005.
Peamemuatengaini menggnbakaikxapisaubataмa penduduk China modern adalah yang pertama yang membuat mie. Mie berkembang dan menyebar ke Jepang, Korea, Taiwan dan Negara-negara di Asia Tenggara bahkan meluas sampai ke benua Eropa. Menurut sejarah Mie mulai dikenal di Eropa setelah Marcopolo berkunjung ke China pada abad ke13 dan membawa oleh-oleh mie. Namun pada perkembangannya di Eropa Mie berubah menjadi Pasta.

Dalam budaya China, mie adalah symbol kehidupan yang panjang, mie sering dsajikan pada acara ulang tahun dan saat tahun baru China sebagai lambang umur panjang.

Di Jepang, mie dimasukkan kedalam tradisi upacara minum teh dan membuat mie dianggap sebagi seni tersendiri di Negara tersebut.Mie bahkan menjadi lebih penting di Jepang setelah Perang Dunia II, ketika kekurangan makanan hanya mie yang tersedia.

\section{E. Jenis Mie}

Ada beberapa jenis mie yang terkenaal di Asia, bentuknya bisa berbentuk tipis, pipih, tebal atau bulat, terbuat dari gandum atau beras, setiap jenis mie memiliki sejarah tersendiri dalam dunia kuliner di negaranya.

1. La Mian Mie

Mie tertua yang pernah di temukan menyerupai mie Mie La Mian modern di China. La Mian secra harfiah berarti “mie tarik". Mie ini dibuat secara manual dengan tangan dan berbahan dasar gandum.

Caranya adonan diplintir dan ditarik samapi panjang yang kemudian dipotong tipis-tipis. Mie disajikan dengan soup dan kentang goreng.

2. Mie Ramen

Orang menyebutnya mie kriting China dijual dalam kondisi kering dalam kemasan mie instan. Sangat cocok diolah sebagai mie goreng ataua mie kuah.

3. Chellophane noodles

Kita mengenalnya dengan sebutan Suun. Suun dibuat dari campuran tepung kentang dan tepung kacang hijau. Mie jenis ini sangat lunak teksturnya cocok untuk olahan soup, sun goreng atau untuk isi pastel. Suun dijual dalam bentuk kering, untuk penggunaannya 


\section{P-ISSN : 0216-7484 \\ DOI : doi.org/10.21009/sarwahita.121.09}

rendam terlebih dahulu dalam air panas sampai lembut dan sun siapp diolah menjadi berbagai masakan.

4. Mie Telur

Terbuat dari tepung terigu jenis hard wheat dan diperkaya dengan telur. Biasanya dijual dalam kondisi kering berbentuk bulat maupun pipih.

5. Hokkien Noodles

Sering disebut denngan mie Hongkong. Bentuknya seperti mie telur bulat dan halus. Biasanya dibuat dalam bentuk basah dalam kemasan kedap udara. Mie ini sangat cocok utnuk dibuat mie rebus atau mie goreng

6. Rice Stik Noodle

Dikenal dengan sebutan Kwetiau. Mie ini dibuat dari tepung beras dan air. Dipasaran dapat kita jumpai dalam bentuk kering dan basah. Kwetiau dapat dibuat kuah dan goreng.

7. Somen noodles

Mie ini berasal dari Jepang, terbuat dari tepung gandum dan minyak. Teksturnya sangata lembut dan gurih. Dijual dalam bentuk kering rupanya menyerupai lidi dan sangat rapuh. Cocok untuk masakan Jepang yang berkuah.

8. Soba noodles

Terkenal denga sebutan mie Jepang, bentuknya hamper sama dengan mie Somen namun warnanya keabu-abuan atau hijau tua ( mengandung sari the hijau). Dijual dalam bentuk kering, dihidangkan dalam bentuk mie kuah.

9. Rice Vermicelli

Di kenal di Indonesia sebagai bihun. Bihun terbuat dari tepung beras, warnanya putih bersih dan teksturnya sangat lembut. Mie ini sangat mudah matang jadi tidak perlu direbus, direndam dengan air panas sudah cukup. Biasanya dijual dalam kemasan plastic cocok untuk isi soup daan bihun goreng.

10. Mie Shoa

Sejenis mie asal China. Terbuat dari tepung beras, mie ini berwarna putih terang dan sangat mudah matang dapat digunakan di dalam soup atau sebagai makanan camilan sebagai miesoa goreng.

11. Wonton
Dikenal dengan sebutan kulit pangsit. Dijual dalam bentuk basah dalam kemasan plastik. Biasanya diolah dengan beragam isi, baik itu di kukus maupun digoreng.

\section{F. Mie dari tepung Mocaf}

Pada kesempatan ini Singkong dapat dimanfaatkan menjadi beragam jenis makanan olahan. Diantaranya adalah untuk membuat mie. Singkong adalah salah satu tanaman pangan yang cukup potensial di Indonesia sebagai sumber karbohidrat, yang produksinya belum optimal karena kurang ekonomis.

Karena itu perlu dikembangkan suatu produk pangan baru berbasis singkong untuk meningkatkan nilai ekonomis singkong sebagai salah satu alternative pengganti terigu dan upaya desirvikasi pangan.

Mocaf adalah produk turunan dari singkong dengan prinsip modifikasi singkong secara fermentasi, produk turunan ini menyumbang sedikit protein sehingga diperlukan bahan sumber protein untuk meningkatkan kandungan protein pada mie. Produk mie yang terbuat dari tepung ini hasilnya sama dengan mie yang terbuat dari tepung terigu biasa.

Hasil pembuatan mie ini dapat digunakan sebagai pelengkap pada mie bakso dan mie ayam dan juga dpat dibuat dengan berbagai resep lainnya

Setelah pembuatan tepung mocaf, pelatihan dilanjutkan kepada proses aplikasi tepung mocaf kedalam pembuatan mie sebagai berikut :

\section{MIE}

Untuk 420 gram

Bahan :

100 gr Tepung mocaf

100 gr Tepung terigu protein tinggi

$1 / 4$ sdt Garam

$1 / 4$ sdt CMC (pengikat dari pati2an)

$1 / 4$ sdt Natrium karbonat (pengenyal mie dan melenturkan mie)

$68 \mathrm{ml}$ Air

Secukupnya Minyak goreng

Alat : 
- Markatto (alat pencetak dan pemotong mie)

- Baskom /wadah plastic

- Panci

- Kompor

- Ayakan

- Timbangan

Cara Membuat :

Ø Campurkan tepung terigu protein tinggi, mocaf, garam, CMC, dan Natrium karbonat dalam wadah plastik.

Ø Tambahkan air, aduk rata lalu gumpalkan.

Ø Giling adonan dengan gilingan mie dari ukuran terbesar sampai ukuran no.2 tiap ukuran gilingan, digiling 2-3 kali sampai licin.

$\varnothing$ Potong-potong menggunakan gilingan mie.

$\varnothing$ Rebus dalam air mendidih hingga matang, lalu angkat kemudian lumuri minyak goreng, aduk rata dan mie siap untuk diolah.

\section{Tips Dalam Membuat Mie}

1. Sebelum digiling, diamkan adonan selama 15 menit agar adonan tidak mudah putus (kenyal) Masukkan hasil mie yang telah digiling ke dalam plastik, agar warna tidak cepat berubah.

2. Ciri mie yang baik adalah kenyal, warna mie rata, tidak mudah lembek bila di rebus dan rasa mie yang lembut.

3. Cara-cara terbaik untuk mengawetkan mie yaitu dikukus, dikukus lalu digoreng, dijemur, dikukus lalu dijemur.

4. Perebusan Mie : Membuat mie dengan tepung terigu protein rendah memerlukan waktu perebusan yang lebih singkat dibandingkan dengan mie yang dibuat dengan menggunakan tepung terigu protein tinggi. Mie yang dibuat dengan tepung terigu berprotein rendah akan cepat lembek bila direbus agak lama.

5. Pemberian Natrium karbonat Apakah berbeda pemberian Natrium karbonat dalam pembuatan mie bila menggunakan tepung terigu protein rendah dengan yang berprotein tinggi? Jelas berbeda, pemberian Natrium karbonat akan lebih banyak pada tepung terigu berprotein rendah bila dibandingkan dengan tepung terigu berprotein tinggi.

6. Telur juga dapat ditambahkan ke dalam adonan mie sehingga citarasa mie menjadi lebih gurih dan warnanya menjadi lebih kuning.

7. Tutup selalu adonan mie dengan plastik atau lap lembab supaya mie tidak kering dan putus saat digiling.

\section{Kandungan Gizi}

Kandungan gizi ideal 1 porsi karbohidarat $=$ 175 kkal

Kandungan gizi bahan :

Tepung terigu $=$ Berat bahan yang digunakan $\mathrm{x}$ $175 \mathrm{kkal}$

Berat bahan 1 porsi $=100 \times 175 \mathrm{kal}=700 \mathrm{kkal}$

25 Mocaf = Berat bahan yang digunakan $\mathrm{x}$ 363 kkal

Berat bahan 1 porsi

$=100 \times 363 \mathrm{kal}=363 \mathrm{kkal}+100$

Total kandungan gizi bahan $=1063 \mathrm{kkal}$

Takaran saji ideal $=420$ gram

$=420$ gram $\quad=70$ gram

\section{KESIMPULAN}

Setelah dilakukan pelatihan keterampilan pembuatan tepung mocaf serta pengaplikasiannya ke dalam pembuatan mie mocaf, maka peserta yang terdiri dari ibu-ibu dan remaja putri Desa Jaya Sakti memiliki pengetahuan dan keterampilan dalam membuat tepung mocaf dan mie mocaf. Pelatihan berjalan dengan lancar dan peserta antusias dalam mengikuti proses pelatihan.

\section{DAFTAR PUSTAKA}

Cereda, M.P. and Mattos, M.C.Y. (1996). "Linamarin - The Toxic Compound of Cassava". Journal of Venomous Animals and Toxins (online) 2 (1), 612; ISSN 0104-7930

Faridah, Ani dkk. Patiseri Jilid 2 untuk SMK. Jakarta : Direktorat Pembinaan Sekolah Menengah Kejuruan, Direktorat Jenderal Manajemen Pendidikan Dasar dan Menengah, Departemen Pendidikan Nasional, 2008. 
Tepung Singkong Dalam: Paket Industri Pangan. Bogor : Pusat Pengembangan Teknologi Pangan. IPB, 1989.

Tri Radiyati dan Agusto, W.M. Tepung tapioka. Subang : BPTTG Puslitbang Fisika Terapan - LIPI, 1990.

Mengolah Singkong menjadi Tepung Mocaf, Bisnis Produk Alternatif Pengganti
Terigu, Emil Salim, Lily Publisher, 2011

Karuniasemesta. wordpress.com/2012/09/01/84 4/Epetani.deptan.go.id/budidaya/teknik -pengolahan-tepung-mocaf-2897

www.spi. or.id/?p=4731

http://www.apakabardunia.com/2011/09/jenisjenis-mie-dan-sejarahnya-sejak.html 